\title{
How the Macroeconomic Environment and Investment Climate Have Affected the Manufacturing Sector
}

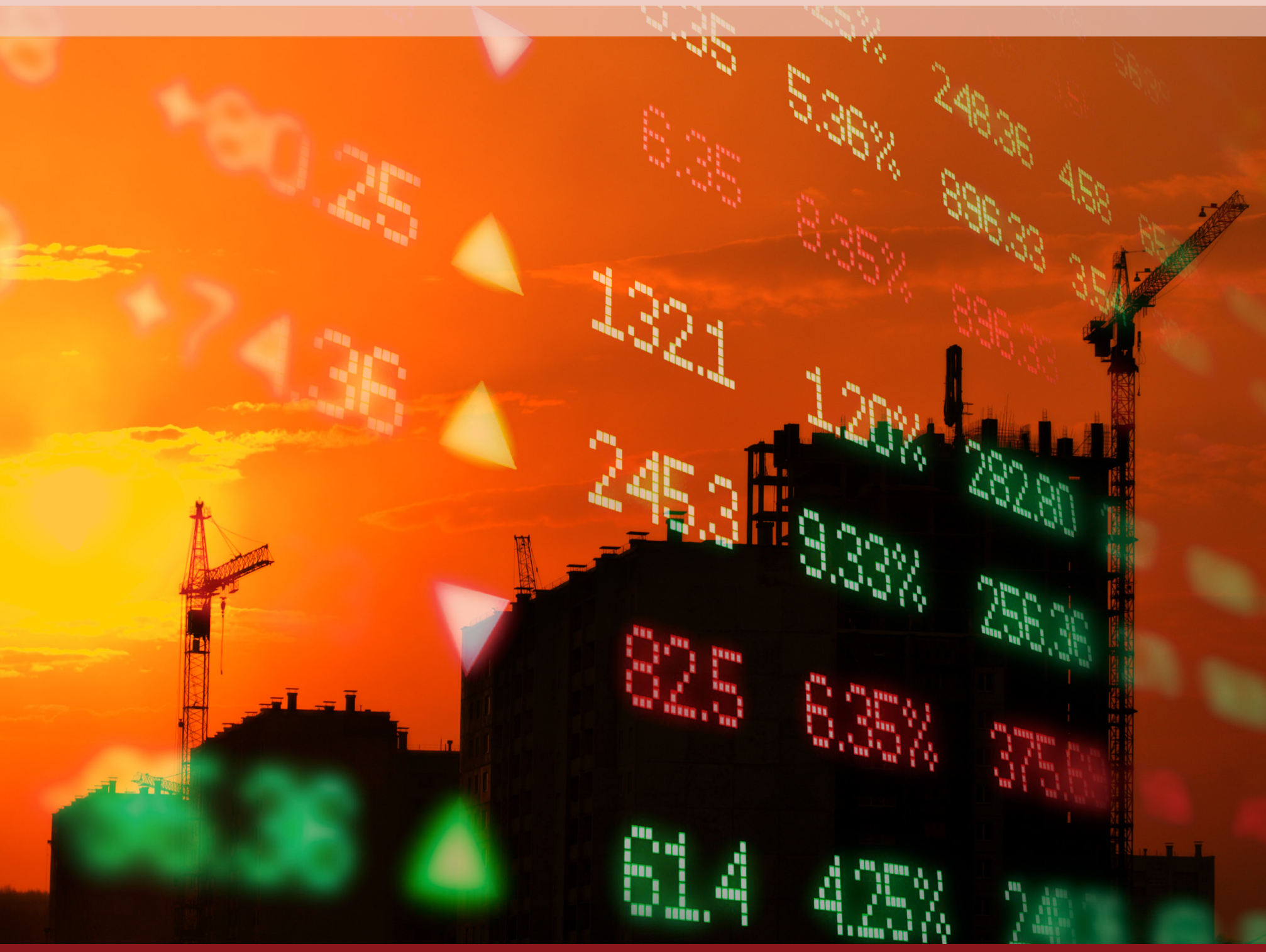


THE WORLD BANK OFFICE JAKARTA

Indonesia Stock Exchange Building, Tower II/12-13th FI.

Jl. Jend. Sudirman Kav. 52-53

Jakarta 12910

Tel: (6221) 5299-3000

Fax: (6221) 5299-3111

Printed in September 2012

How the Macroeconomic Environment and Investment Climate Have Affected the Manufacturing Sector is a product of staff of the World Bank. The findings, interpretations and conclusions expressed herein do not necessarily reflect the views of the Board of Executive Directors of the World Bank or the governments they represent.

The World Bank does not guarantee the accuracy of the data included in this work. The boundaries, colors, denominations and other information shown on any map in this work do not imply any judgment on the part of the World Bank concerning the legal status of any territory, or the endorsement of acceptance of such boundaries.

Cover photograph is: Royalty free photo online from istockphoto.com. All rights reserved. 


\title{
Policy Note 3
}

\section{How the Macroeconomic Environment and Investment Climate have Affected the Manufacturing Sector}

\begin{abstract}
Contributors: Gonzalo Varela, Swati Ghosh and Sjamsu Rahardha

The performance of Indonesia's manufacturing sector has lagged over the past decade. This is seen in the decline in growth after the Asian financial crisis, by the sector's decline relative to other sectors within the economy, and relative to countries in the region. This note documents the effects of the challenging macro and external environment on the profits of manufacturing firms, and on the uncertainty they face, and argues that these adverse conditions partially explain the stagnation of the sector in the past decade. The changes in incentives appear to have particularly affected labor-intensive sectors, with important consequences for job creation. Policies to promote growth in the manufacturing sector should aim at alleviating pressures on manufacturing costs by: (i) reducing rigidities in the market for labor; (ii) promoting competition in the market for services; and (iii) providing incentives for productivityenhancing technology adoption, while reducing profit uncertainty by (iv) maintaining a low and predictable rate of inflation and (v) keeping exchange rate volatility within reasonable limits.
\end{abstract}

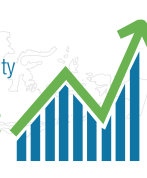

Schweizerische Eldgenossenschaft

Confederation sulisse

Confederazion svizra

Swiss Confoderation 


\section{Table of Contents}

\section{Introduction}

2. What has happened to profitability?

3. Macroeconomic factors have increased the opportunity costs of operating in manufacturing

4. The Underlying Factors behind the Deterioration of Profit Margins at the Firm Level

a Pressures on Revenues

b Pressures on Costs

c Increased Uncertainty

d Conclusions and Broad Policy Recommendations 


\section{Introduction}

Indonesia has achieved macroeconomic stability, and demonstrated strong and sustainable growth, as well as a solid fiscal position. All of these are factors that encourage the private sector to grow. However, the manufacturing sector remains confronted by a challenging external environment, and by specific aspects of the macroeconomic context.

Figure 1: Roadmap for the policy note

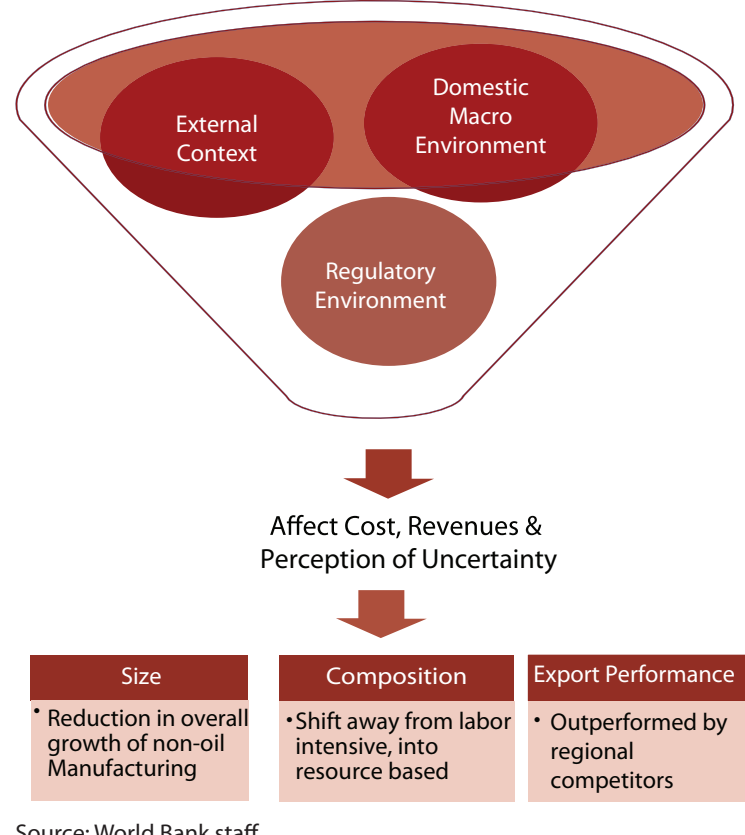

Source: World Bank staff.
To what extent can the decline in the growth rates of manufacturing and in manufacturing export performance seen since the Asia financial crisis be attributed to developments in Indonesia's macroeconomic environment and its investment climate? Have improvements in the profitability of other sectors, notably services and commodities, reduced the incentives for manufacturing production? Has the appreciation in the real exchange ratealso associated with the commodity boom and capital inflows-rendered Indonesia's exports less competitive? Has the investment climate been a key factor in Indonesia's deteriorating performance, particularly in the face of competition from other economies competing in the same products? Are any of these factors specific to Indonesia, or did they equally affect all economies in the region? This policy note analyzes the role that the macroeconomic environment may have played in the decline in the performance of the Indonesian manufacturing sector.

\section{What has happened to profitability?}

The average rate of return across listed firms in the East Asia region has dropped significantly. ${ }^{1}$ The average rate of return on the equity of listed firms in Indonesia, Malaysia, the Philippines, and Thailand declined from 13 percent during 1990-96 to under 6 percent in 1999-2010.

While this declining trend could to some extent be a reflection of the de-leveraging that firms in these countries have undertaken since the Asian financial crisis (Figure 2), this trend is also seen in the ratio of net income to sales-which is also a measure of the rate of return but is less sensitive to changes in leverage. ${ }^{2}$ The ratio of net income to sales fell from 10 percent during 199096 to 5.7 percent in 1999-2010. At the same time the average risk faced by listed firms in the region, as measured by the variability (standard deviation) of returns over sales, increased from 11 percent to 20 percent over the same periods.

\footnotetext{
The rates of return are calculated across listed firms in Indonesia, Malaysia, the Philippines, and Thailand. For Vietnam data are available only for the period 2000-10.

The Asian financial crisis triggered a process of deleveraging among firms that relied heavily on debt. In this restructuring process, shareholders had to contribute more equity, driving return on equity down. In fact, for the median firm in the Southeast Asian region (Indonesia, Malaysia, the Philippines, and Thailand), the ratio of debt to equity — a typical measure of leverage — fell by 22 percent. In Indonesia, this drop was 10 percent.
} 
Figure 2: Firms in East Asia deleveraged after the Asian financial crisis

(Total liabilities/equity for listed firms)

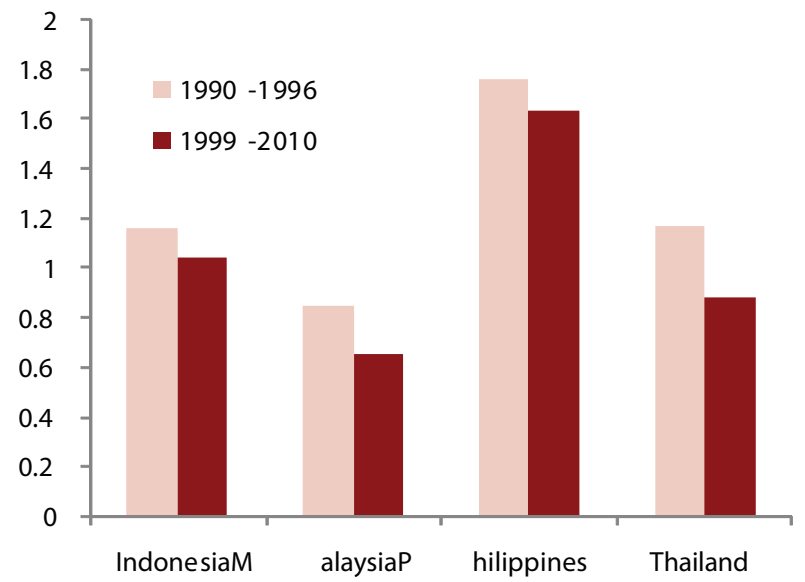

Source: World Bank staff calculations based on Bloomberg.
The downward trend in the average rate of return and the increase in risk have been more marked in Indonesia. In Indonesia, the average rate of return on equity across listed firms dropped from 14 percent during $1990-96$ to 7.5 percent during 1999-2010, while the return as measured by income to sales dropped from 11 percent in the pre-East Asia crisis period to 4 percent during 1999-2010 (Figure 3and Figure 4). The increase in average risk, as measured by the standard deviation of income to sales, was particularly strong in Indonesia from 5.8 percent in the pre-crisis period to over 26 percent during 1999-2010 - three times the increase in risk seen in the other three Southeast Asian countries.

Firms in the textile and garment industries - the largest labor-intensive sectors - were particularly affected. The average rate of return in these sectors across the region dropped sizably (from 6 percent during 1990-96 to -0.5 percent during 1999-2010), while the profit risk faced increased (from 4 percent to 13 percent) across the region. Again, the trend was more marked in Indonesia where these sectors' returns declined from an average of 5 percent to -6 percent in the two periods, and their risk (standard deviation of returns) rose from 4.7 percent during 1990-96 to 31 percent during 1999-2010.

Figure 3: Firms' rates of return dropped after the crisis...

(Rates of return on sales for listed firms)

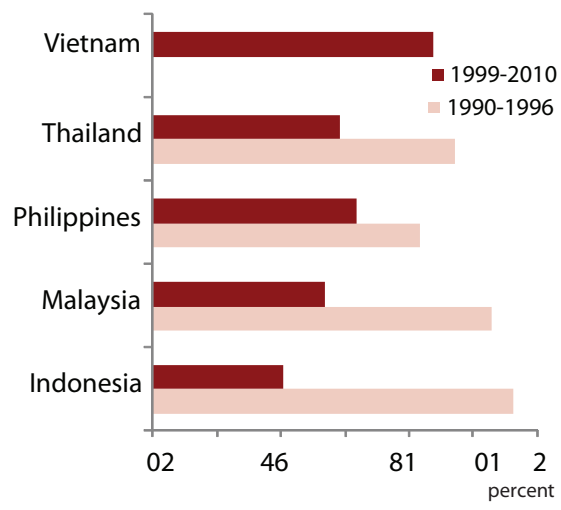

Source: World Bank staff calculations based on Bloomberg.
Figure 4:....while profit risk rose (Standard deviation of rates of return for listed firms)

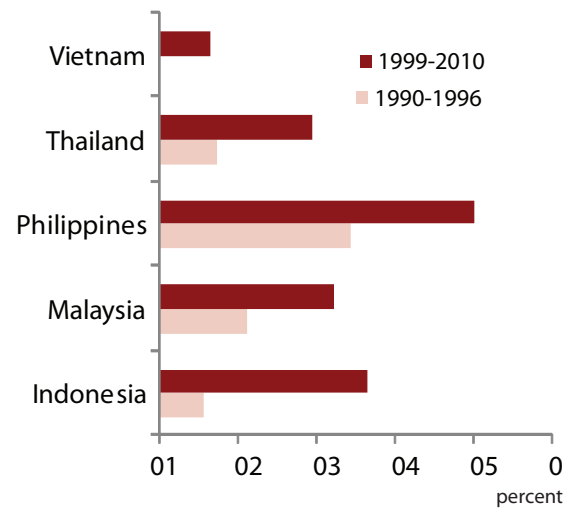

Source: World Bank staff calculations based on Bloomberg.

Average returns for services and natural resource firms are significantly higher than returns for manufacturers, once these returns are adjusted for firms' risk. ${ }^{3}$ Figure 5 shows that with the exception of manufacturing firms in chemicals, pharmaceuticals and automotive parts, the postcrisis returns were higher than the average for non-manufacturers.

To be able to compare rates of returns for comparable levels of risk, we construct a measure of returns'conditional on risk' by taking the residual from an OLS regression of rates of return on profit risk (which in turn is calculated as the volatility of previous returns). 
Figure 5: Firms in services and mining industries exhibit higher returns than manufacturing firms. (Returns to sales across listed firms in Indonesia's Stock Exchange (deviations from the mean) 2000-10)

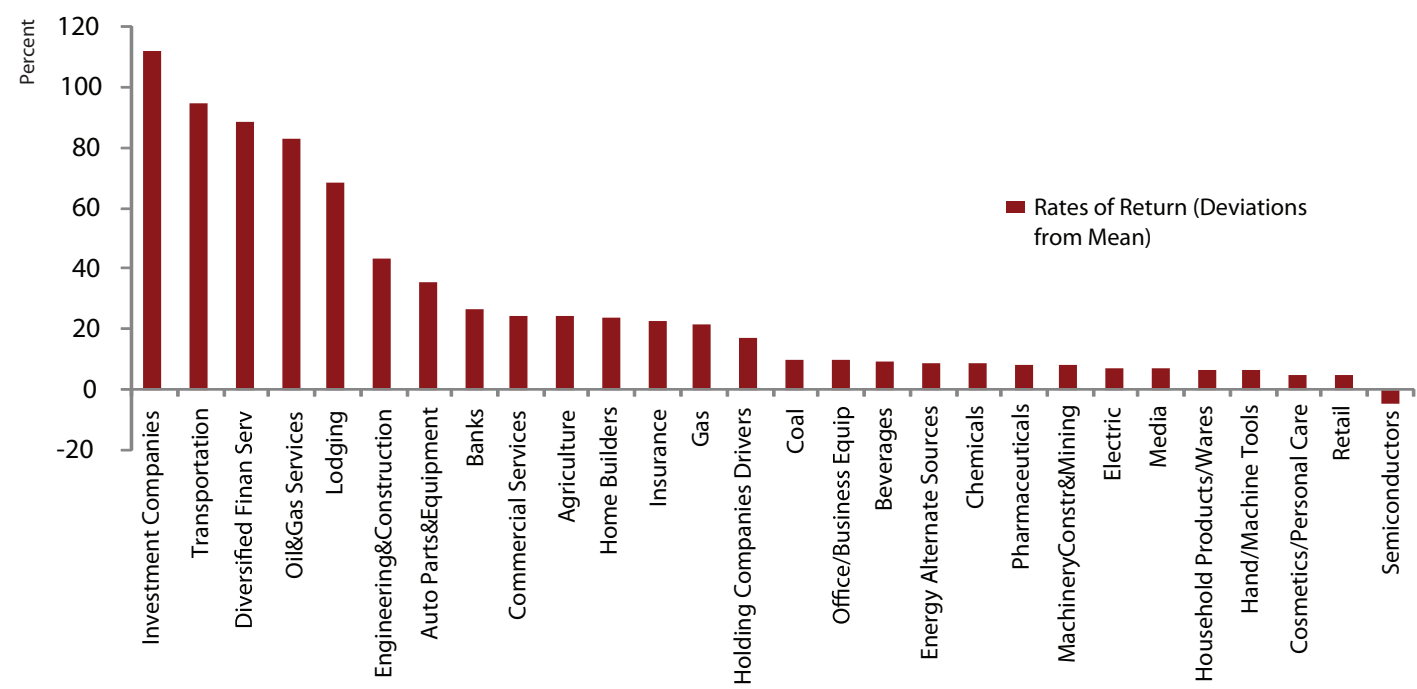

Source: World Bank staff calculations based on Bloomberg.

As discussed in the following sections, several factors on the macroeconomic front are limiting the revenues earned in manufacturing relative to those in other sectors, raising their costs, and as well as increasing the degree of uncertainty under which they operate. Together these factors are reducing the relative profitability of the manufacturing sector and ultimately affecting growth of outputs and the exports of the sector.

\section{Macroeconomic factors have increased the opportunity costs of operating in manufacturing}

A number of macroeconomic indicators suggest that the decline in profitability in the listed manufacturing firms reported above reflects a generalized trend affecting most firms in the non-resource-based manufacturing sector.

The real exchange rate has strongly appreciated since the early 2000 s as a product of high price inflation relative to that experienced by competitors, and a combination of increased capital inflows and a commodity boom that prevented the nominal exchange rate from depreciating. The real exchange rate appreciated by about 42 percent over the first decade of the 2000 s (Figure 6). ${ }^{4}$ This was a consequence of the high inflation rates that Indonesia experienced during the period. Both consumer and producer price inflation rates were about four times higher in Indonesia than in China or Thailand, and substantially higher than the Philippines, Malaysia, India or Vietnam (Figure 7). Typically, the nominal exchange rate would have depreciated enough to compensate for the inflation rate differentials with competitors, so that the external balance was maintained. However, that adjustment was to some extent prevented by the combination of a commodity price boom and strong capital inflows (Figures 8 and 9). Both of these factors contributed towards maintaining an external balance at a higher real exchange rate. Several indicators suggest that the current level of the real exchange rate is at an 'equilibrium' from a macroeconomic perspective (see Box 1).

\footnotetext{
This corresponds to the appreciation of the CPI based real effective exchange rate calculated by the Bank for International Settlements.
} 
Figure 6: The real exchange rate has been appreciating since the early 2000 s...

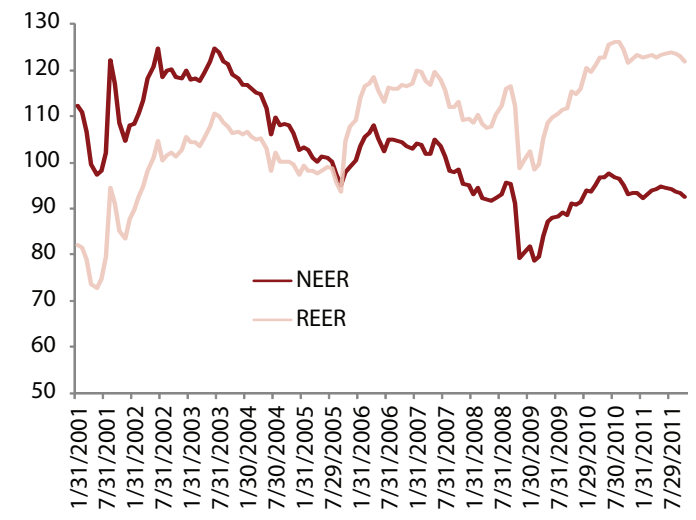

Source: World Bank staff calculations.
Figure 7: ... as a product of Indonesia's relatively higher inflation rates...

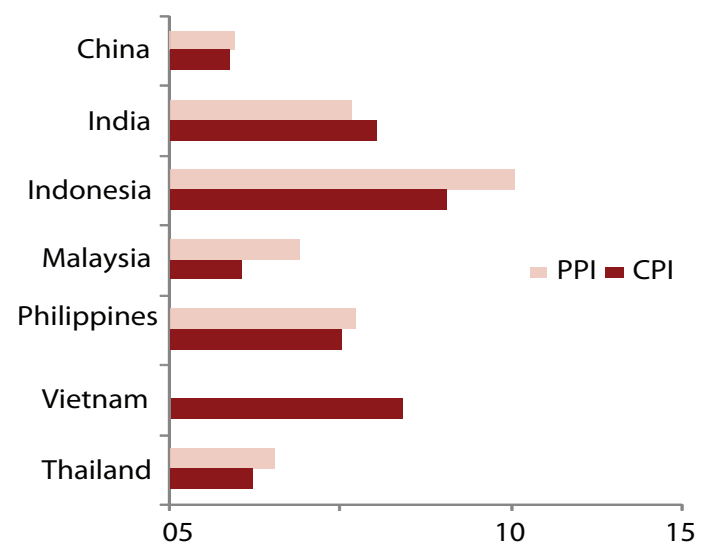

Source: World Bank staff calculations based on BPS

Manufacturing prices have increased at a slower pace than those of the non-tradable and commodities sectors, resulting in a decline in the relative price of manufactures. Over the first decade of the $2000 \mathrm{~s}$, the relative price of manufactured outputs decreased at an average annual rate of 3.4 percent. ${ }^{5}$ As shown in Figure 8, the evolution of this indicator is associated with the rate of growth of value-added in non-oil manufacturing.

Figure 8: ...buoyant commodity prices...

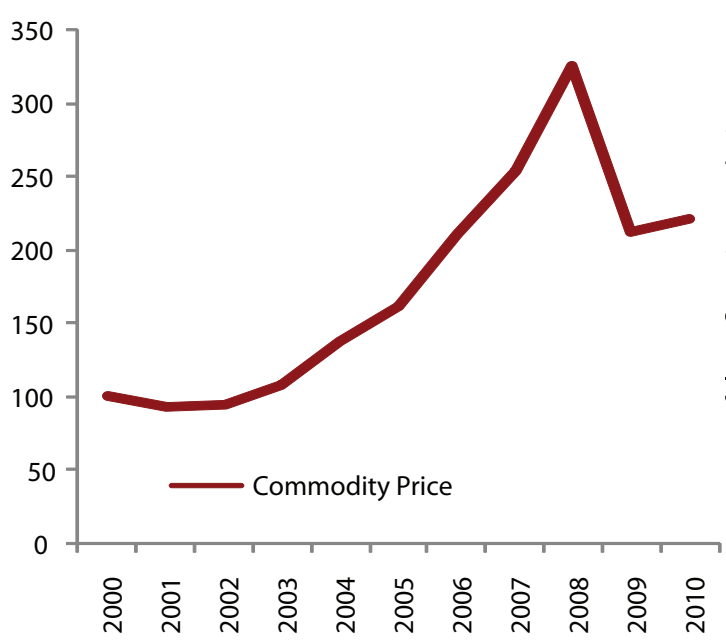

Source: World Bank staff calculations.
Figure 9: ....and strong and increasing capital inflows that prevent the nominal exchange rate from depreciating

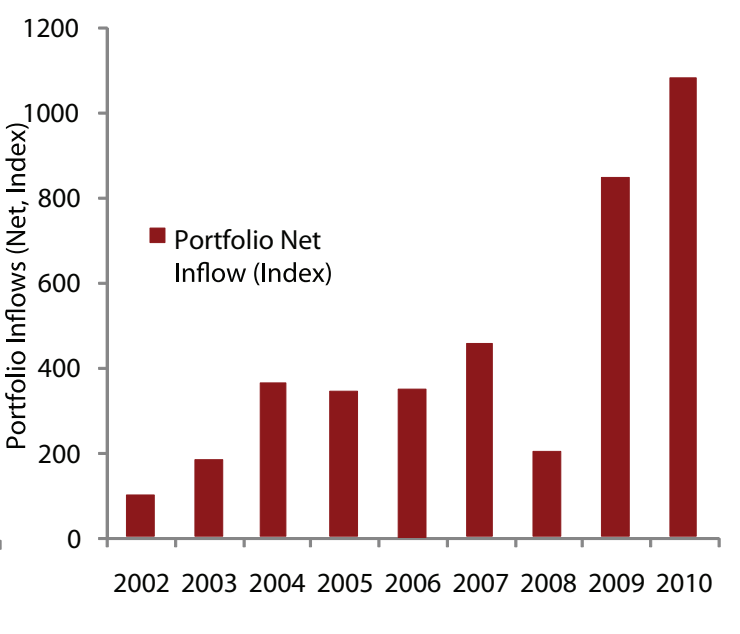

Source: World Bank staff calculations based on BPS.

The manufacturing (tradable) price index corresponds to the value-added deflator of non-oil manufacturing, obtained from national accounts data (BPS). The non-tradable price index is a weighted average of the value added deflators from electricity, gas and water, construction, and private services, obtained from national accounts data (BPS). 


\section{Box 1: Exchange Rate Assessment, Dutch Disease and Growth ${ }^{6}$}

Indonesia's real effective exchange rate (REER) is broadly in line with its macroeconomic fundamentals. Despite the substantial appreciation experienced during the past decade, recent analysis for Indonesia carried out by the IMF suggests that Indonesia's REER is aligned with its fundamentals, with two of the three measures showing a slight undervaluation. These are the "external sustainability" approach, which computes the current account position that would stabilize net foreign assets at a benchmark level (chosen to be that of 2010 for the case of Indonesia, of 35 percent of GDP) and reveals a 9-percent undervaluation, and the "equilibrium real exchange rate" approach, that estimates equilibrium based on a regression analysis and indicates a 6-percent undervaluation. The macro balance approach, on other hand, estimates the current account deficit norm for the medium term at 0.7 percent of GDP, which is close to (and below) the IMF projection for the medium-term current account deficit, thus suggesting a slight overvaluation.

Indonesia's real effective exchange rate (REER) is broadly in line with its macroeconomic fundamentals. Despite the substantial appreciation experienced during the past decade, recent analysis for Indonesia carried out by the IMF suggests that Indonesia's REER is aligned with its fundamentals, with two of the three measures showing a slight undervaluation. These are the "external sustainability" approach, which computes the current account position that would stabilize net foreign assets at a benchmark level (chosen to be that of 2010 for the case of Indonesia, of 35 percent of GDP) and reveals a 9-percent undervaluation, and the "equilibrium real exchange rate" approach, that estimates equilibrium based on a regression analysis and indicates a 6-percent undervaluation. The macro balance approach, on other hand, estimates the current account deficit norm for the medium term at 0.7 percent of GDP, which is close to (and below) the IMF projection for the medium-term current account deficit, thus suggesting a slight overvaluation.

Even if aligned with its fundamentals, a continuously appreciating REER affects the relative size of the non-resourcebased manufacturing sector, with potential implications for long-term growth. It is likely that commodity price growth will remain relatively strong due to the dynamism of emerging markets. In addition, Indonesia's recent performance, combined with its large domestic market, and natural resource abundance will continue to attract capital flows. While this is clearly advantageous for Indonesia's producers of natural resources, it also raises some risks and challenges for those in nonresource-based tradable sectors, whose competitiveness is undermined. The concerns around this sectoral reallocation of resources due to the so-called "Dutch Disease" (the decline of the non-resource-based manufacturing sector due to a boom in resource-based activities), are based on the idea that manufacturing tradable sectors are better positioned to stimulate growth and innovation in the long term due to increasing returns to scale, learning by doing and spillover effects. ${ }^{6}$

Although the empirical evidence on the links between real exchange rates and long-term growth is mixed (as is the literature linking the size of the manufacturing sector and growth), their effects on manufacturing employment and value-added are well documented. Rodrik (2008) and Rodrik and McMillan (2011), for example, point to the importance of undervalued real exchange rates for long-term growth and to the importance of the size of the manufacturing sector for productivity and ultimately growth, respectively. Others, like Magud and Sosa (2011) argue that deindustrialization has no growth implications. The authors carried out a meta-data analysis of more research on Dutch Disease and growth, and found no evidence of Dutch Disease-induced sectoral reallocation of resources having growth effects. On the other hand, these authors do find substantial evidence of employment and value-added contractions in non-resource-based manufacturing after Dutch-Disease type of episodes. Policy Note 1 in this series discusses the importance of the manufacturing sector in a country like Indonesia.

Source: IMF Indonesia report for the 2011 Article IV consultation (2011), Rodrik, D. "The Real Exchange Rate and Economic Growth", Brooking Papers on Economic Activity (2008); Rodrik, D. and McMillan, "Globalization, Structural Change and Productivity Growth", NBER 17143, (2011); Magud, N. and S. Sosa "When and Why Worry About Real Exchange Rate Appreciation? The Missing Link between Dutch Disease and Growth", IMF Working Paper 10/271 (2010).

The term "Dutch Disease" was coined in 1977 by the British newspaper, The Economist, to describe the decline of the manufacturing sector in the Netherlands after the discovery of natural gas towards the end of the 1950s. 


\section{The Underlying Factors behind the Deterioration of Profit Margins at the Firm Level}

The macro indicators of manufacturing profitability discussed above are reflecting a generalized deterioration of profit margins in the sector that occurs at the level of the firm. We conducted a detailed analysis across 31,452 manufacturing plants in Indonesia, which suggests that over the period 1998-2008, profit margins declined at an average annual rate of 1.8 percent. The decline responded both to pressures on revenues and on costs.' In addition, manufacturers faced an increase in the degree of uncertainty in the economic environment in which they operated.

\section{a. Pressures on Revenues}

On the revenue side, tougher export markets implied that exporters' profit margins actually declined at almost double the average rate across the manufacturing sector as a whole, at about 3.4 percent per year. Downward pressure on output prices due to increased competition in export markets can be expected to drive profit margins down, at least until efficiency gains can assimilate the price reductions. Indeed, this is what is observed when comparing the output prices of exporters and non-exporters. The profit margin of exporters was found to be on average 9 percent higher than that of non-exporters, but the profit margin of exporters has been declining over time at a faster rate than that of non-exporters. As a consequence, the exporter profit premium narrowed over time (Figure 10). Competition puts a cap on tradable output prices, and constrains firms in their ability to increase them. In fact, output prices for Indonesian exporters grew, on average, 17 percent less than those for non-exporters.

Increases in import penetration in domestic markets also constrained import-competing firms in their ability to fully pass on price increases. An analysis of determinants of manufacturing output prices suggests that an increase in import penetration of 10 percent would reduce the growth rate of output prices by 2.5 percent. $^{8}$

Figure 10: Relative prices of manufactures are Figure 11: Pressure on profit margins associated with growth of non-oil manufacturing (Profit margins in Indonesia's manufacturing (1998-2008)) value-added

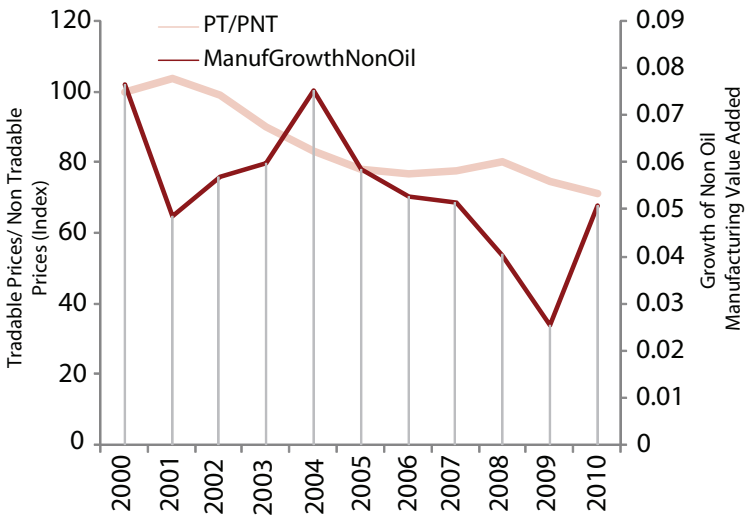

Source: World Bank staff calculations based on BPS data.

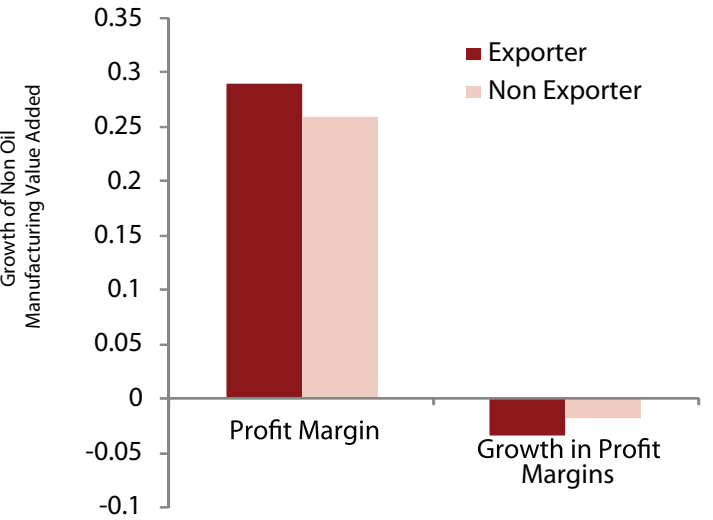

Source: World Bank staff calculations based on BPS data.

\footnotetext{
For the analysis, we used the manufacturing census data from BPS. Profit margins are defined as the difference between output revenue and production costs, relative to costs. Production costs include intermediate input bills, fuel and electricity costs, total labor costs, and an imputed cost of capital. The regression analysis performed, consists of running a fixed effects model of these margins, on a number of firm characteristics (exporting condition, factor intensities and capital stocks), a measure of competition at the sectoral level (Herfindahl index), external and macro environment indicators (import penetration, exchange rates, growth in GDP per capita), and time trends. Estimation results are reported in Table A of the Appendix.

This result emerges from an examination of the evolution and determinants of 31,452 plants' output prices during the post-crisis period (1998-2008), using the manufacturing census data. Estimation results are reported in Table B of the Appendix.
} 
Figure 12: Import penetration has been increasing substantially

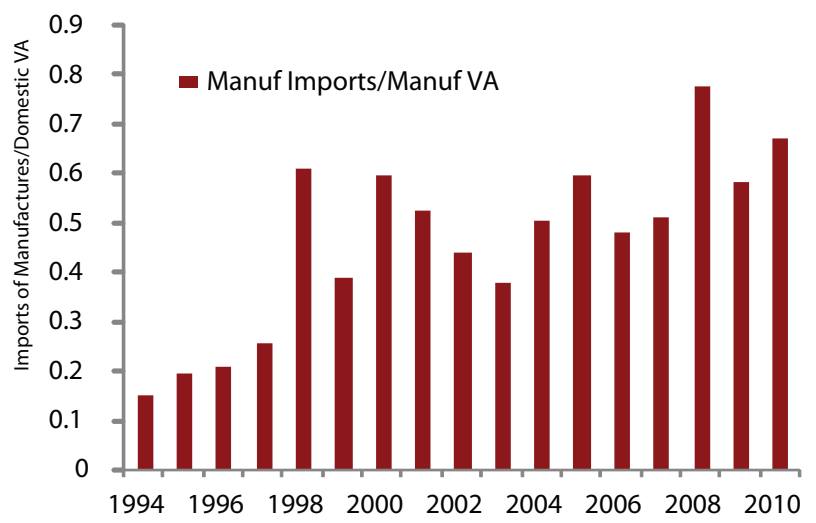

By reducing output prices, increased competition via imports has also affected the profit margins of importcompeting firms since 2005, although the effect has been relatively small. While this 'pro-competition' effect on prices of import penetration has increased the welfare of Indonesia's consumers, it has contributed to squeeze margins of domestic manufacturers.

Source: World Bank staff calculations based on Comtrade and Industrial Census.

A 1 percent increase in the ratio of imports to domestic value-added in a given sector reduces the profit margins by just one tenth of a percentage point (for an indicator of import penetration, see Figure 8). The small effect that import penetration has on margins is related to the fact that a large share of imports is actually intermediate inputs used by domestic manufacturers. The reason why import penetration appears to have only affected prices and profit margins since 2005 may have to do with a change in the composition of imports since then, with a higher penetration of imported products that compete directly with Indonesian products. The change in import composition, in turn, may be in part due to the tariff reductions associated with regional trade agreements that were effective in 2003 but were only implemented beginning in 2005. ${ }^{9}$

Profit margins are also sensitive to exchange rate movements, but the effect is less than one to one. An appreciation of 1 percent, for instance, decreases profit margins by about one third of a percentage point. Since manufacturers use tradable inputs, appreciations affect not only revenues but costs, decreasing them, and yielding a net effect on margins that is significantly smaller than the initial appreciation.

\section{b. Pressures on Costs}

On the cost side, prices of non-tradable goods have increased threefold in the period 2000-10. This is the result of a combination of more than a decade of sustained growth that strained existing infrastructure capacity and a commodity boom that has increased demand for labor and services, where competition is limited due their non-tradable nature. The net impact has been cost-push forces that have raised non-tradable prices.

Manufacturing wages have risen faster than the increase in labor productivity, resulting in rising unit labor costs during most of the first decade of the 2000s. Unit labor costs have risen particularly sharply for labor-intensive sectors such as textiles, wearing apparel, and furniture (Figure 13)..$^{10}$ One of the reasons for the rapid increase in unit labor costs is related to the fact that the flexible labor markets in pre-crisis Indonesia meant that the sharp decline in output during 1997-98 translated into the labor market via wage reductions rather than via employment falls. This means that the starting point for wages was significantly low. In any case, unit labor cost increases are likely to have

\footnotetext{
ASEAN China FTA was effective in July 2003 but began to be implemented in 2005; ASEAN Korean FTA began implementation in July 2006; and Indonesian-Japan Economic Partnership Agreement began implementation in July 2006.

These results are consistent with the findings of Aswicahyono, Narjoko, and Hill "Industrialisation after a Deep Economic Crisis: Indonesia”, Journal of Development Studies, Vol. 46: 6, 1084-1108,(2010).
} 
influenced the decision of firms to adopt technologies that helped decrease their reliance on labor. ${ }^{11}$ In fact, previous studies reported that the economic recovery post-crisis has had a limited impact on employment, at least in the formal sector. ${ }^{12}$ While 1 percent growth in manufacturing value-added in the 1990s implied the creation of about 46,000 jobs, the same percentage increase implied the addition of fewer than 33,000 jobs during the first decade of the 2000s (Figure 14).

Figure 13: Labor costs have tended to outpace labor productivity resulting in rising unit labor costs

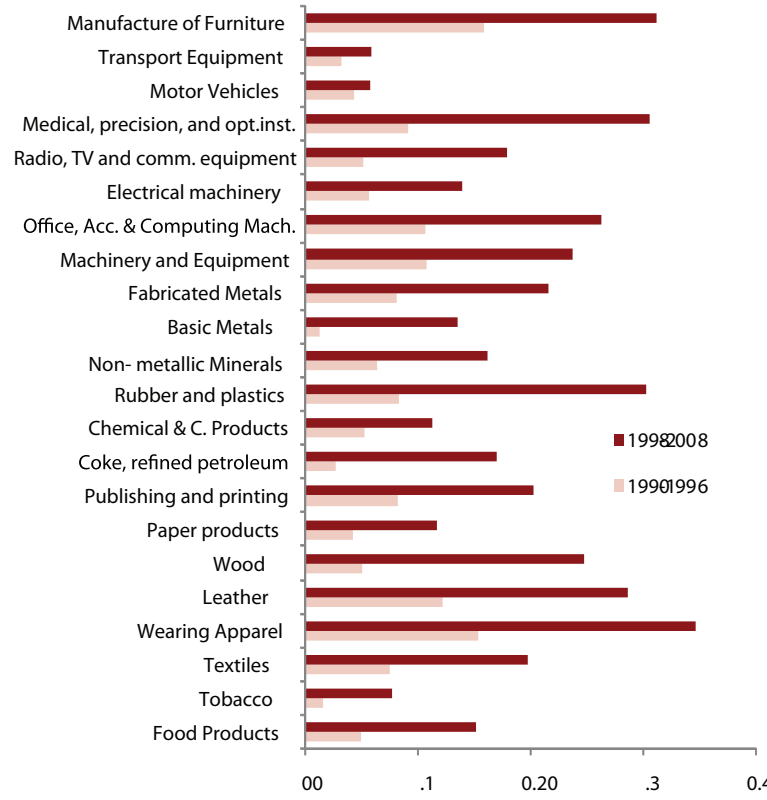

Source: World Bank staff calculations based on Industrial Census.
Figure 14: "Jobless growth": the employmentvalue-added elasticity dropped substantially in the 2000s

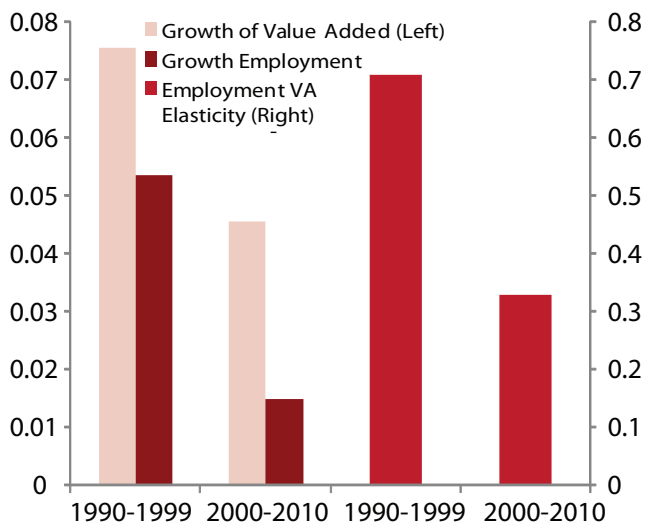

Source: World Bank staff calculations based on BPS data.

Some aspects of the labor regulations have also contributed to increased non-wage costs of labor. Changes in Indonesia's labor law were introduced in 2003 (Manpower Law No. 13/2003), which aimed to improve workers' protection. The most significant changes in the law increased firing restrictions, decentralized minimum wage setting (changing the process of how the minimum wage was set-not changing the minimum wage itself) and placed restrictions on how contract workers could be used. ${ }^{13}$ The three aspects have interrelated effects: since the severance payouts are based on workers' wages, any changes to the minimum wages would also carry through and affect the severance payout; firms may respond to increased severance payouts by increasing their use of contract workers but the legislation made this more difficult by limiting the types of activities contract workers are permitted to do and by limiting the length of their contracts (to a total of three years after all possible renewals and extensions).

\footnotetext{
The unit labor costs reported here are calculated until 2008.

Aswicahyono, Narjoko, and Hill (2010).

13 Manning, C. and K. Roesad "The Manpower Law of 2003 and its implementing regulations: Genesis, key articles and potential impact," Bulletin of Indonesian Economic Studies, Taylor and Francis Journals, vol. 43(1), pp. 59-86 (2007).
} 
Figure 15: Indonesian average wages in recent years have come in below those in China and Vietnam

(Unit labor cost index, US\$, 2005=100)

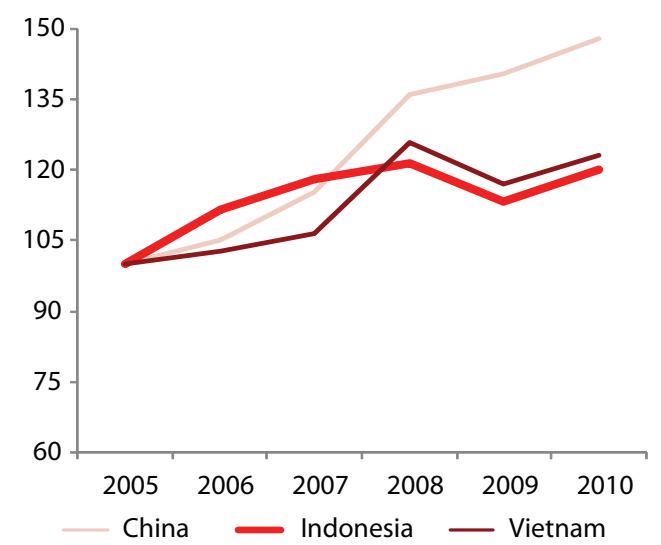

The recent slowdown in unit labor costs in Indonesia relative to other countries in the region could be an opportunity for the revival of labor-intensive sectors. It is worth mentioning that data covering more recent years suggest that growth of unit labor costs in Indonesia has slowed, while it has soared in other competitor countries. For example, media reports have been highlighting that rapidly increasing wages in China, particularly in industrial cities, have triggered firms in labor-intensive industries, such as TCF, to relocate to Cambodia and Indonesia. China's wages are estimated to have increased significantly faster than those in Indonesia over the past 3-4 years, particularly in industrial areas of the Pearl River Delta and the Yang Tze River.

Source: Economist Intelligence Unit, 2010, and World Bank staff calculations.

However, the impact of recent hikes in minimum wages in Java on efficiency-seeking foreign investors is uncertain. As highlighted above, average wages have been increasing slowly, and have not outstripped inflation in the recent years, even if minimum wages have done so.

\section{Box 2: Employment-to-Value-Added Elasticity}

The responsiveness of employment to value-added increases has been decreasing over time. Known as "employmentto-value-added elasticity", it measures the percentage growth in employment for each 1 percent increase in value-added. It has declined from about 0.7 in the 1990 s to slightly more than 0.3 in 2000 s (Figure 14 above). Buoyant commodity prices, and changes in macro incentives favoring resource-based and discouraging labor-intensive manufacturing, combined with the increases in labor costs experienced over the past decade, may explain this decline.

The decline in employment-to-value-added elasticity has been due to both a change in the composition of manufacturing away from labor-intensive manufacturing sectors, and to a within-firm decrease in the labor intensity. The first effect is evident in the left-hand figure below, which shows the changes in the structure of manufacturing in Indonesia, with a decreasing importance in total value-added of labor intensive sectors, and an increasing importance of resource-based and capital intensive activities over the decade. The second effect, capturing the intra-firm decrease in labor intensity, is found when analyzing how the relation between employment creation and value-added evolved at the firm level. The evidence suggests that the employment-value-added elasticity has exhibited a significant downward trend of around 0.15 percent per year (controlling for investment). ${ }^{14}$ Moreover, the more labor-intensive manufacturing sectorsnotably textiles, garments, wood products and furniture-which as expected have higher than average employment-tovalue-added elasticities, are the sectors that have seen the greatest declines (right-hand figure below). ${ }^{15}$ Overall, this is also consistent with findings by Aswicahyono, Narjoko, and Hill (2010).

Female workers have been disproportionally hit by the declining employment-value added elasticity. This is because these labor intensive sectors are also the ones employing the largest shares of the female labor force. In fact, 47 percent of all females working in the manufacturing sector are employed in the textile, garment, leather and furniture industries.

We use a panel dataset of Indonesian manufacturing firms and run a fixed effects model of employment on value added, controlling fo investment levels. The fixed effects allow us to capture the within-firm relationship between employment and value added.

Economic theory predicts that the impact of a law such as the one approved in Indonesia in 2003 raises the overall cost of labor, which will cause the firm to use less of that more expensive input (labor) and more of the other input (capital) than previously. However, the law also restricts the ability of the firm to reduce its workforce so the overall effect on labor is ambiguous. The increased costs of production will also lead to lower output. The direct effect of the policy on labor costs is to increase them, though if enough firms decrease the amount of labor employment, there could be an overall (general equilibrium) effect of lowering wages for workers. Minimum wages rose significantly following the East Asia crisis, and evidence suggests that increases in minimum wages in Indonesia pushed up the wages of some categories of workers, while the wages of other workers remained depressed, with no significant effect on average wages overall. However the increases in minimum wages did have a negative impact on urban formal sector employment, except for white collar workers (SMERU 2001). 
Figure 16: The importance of labor-intensive sectors is declining

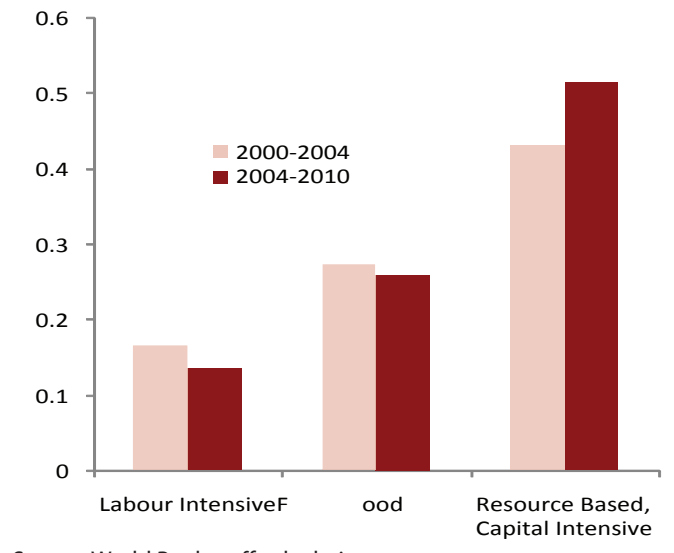

Source: World Bank staff calculations.
Figure 17: Most manufacturing sectors have seen a decline in the employment-to-value-added elasticity

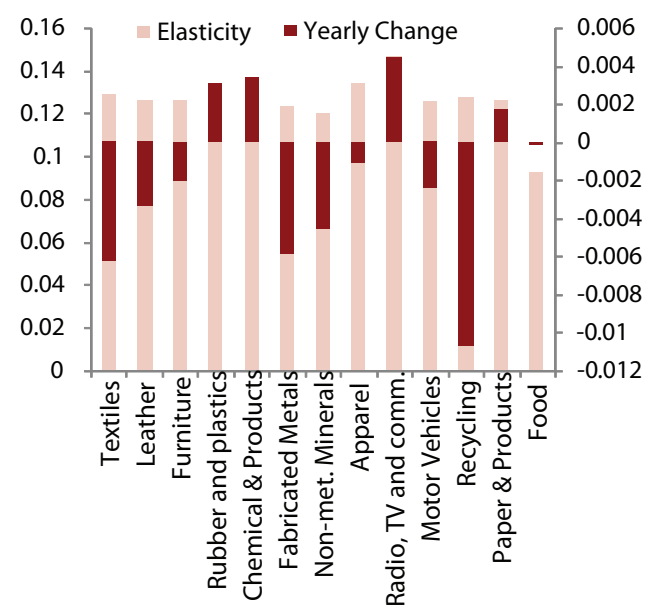

\section{c. Increased Uncertainty}

Increased uncertainty with respect to prices and demand levels has added pressure on manufacturers. In addition to the pressures on revenues and costs highlighted above, both the domestic and the external macro environments have increased the degree of uncertainty under which they operate. Increases in uncertainty typically induce manufacturing firms to postpone investment plans or even move resources away from productive activities that exhibit some degree of irreversibility. For most of the first decade of the 2000s, exchange rate uncertainty, measured by the volatility of the exchange rate, has been relatively high compared with other countries in the region (Figure 18). Such volatility is likely to have an adverse impact on manufacturers, especially on exporters, as it generates uncertainty with respect to the price to be received for their outputs. ${ }^{16}$

In addition, the recent global turbulence affecting the developed economies is likely to have added demand uncertainty to Indonesia's manufacturing exporters. This is because despite the increase in importance of the region and the domestic market as a destination for its outputs, the manufacturing sector still relies substantially on European and US markets which, over the period 2000-10, constituted the destination of about half Indonesian manufacturing exports. That dependence makes the sector vulnerable to economic fluctuations in those markets, particularly because Indonesian exports are relatively elastic with respect to world income (see Box 3). For example, if we take food and beverage, the sector with the largest exposure to the European Union, our estimates suggest that the direct effect of a 1 percent contraction of GDP in the EU on exports would imply a reduction of roughly 0.97 percent (Figure 19$).{ }^{17}$ Total effects are probably larger since a contraction in economic activity in the EU would be likely to affect the GDP of other important Indonesian trading partners such as Singapore and China.

Exchange rate volatility in Indonesia has declined substantially since 2009, which has led to a more stable environment for manufacturers, and tradable producers in general.

To calculate these effects, we estimated export supply and demand functions for Indonesian manufactures and identified the elasticity to world income. The export effect of a contraction in income of a given trading partner is calculated as the product of the elasticity of exports to world income, the share of the partner's demand for Indonesian exports on total demand and the hypothesized contraction in income. 
Figure 18: The Indonesian rupiah has been more volatile relative to other currencies (Currency volatilities against the US dollar)
Figure 19: Indonesia's manufacturing exports would be exposed to a slowdown in US or EU markets (Estimated effects on Indonesian manufacturing exports of a $1 \%$ decline in GDP in US or EU)

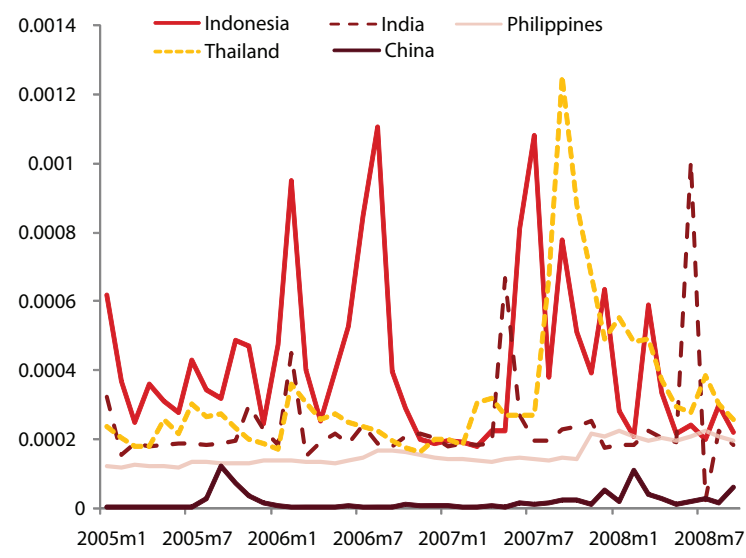

Source: World Bank staff calculations based on IMF IFS data.

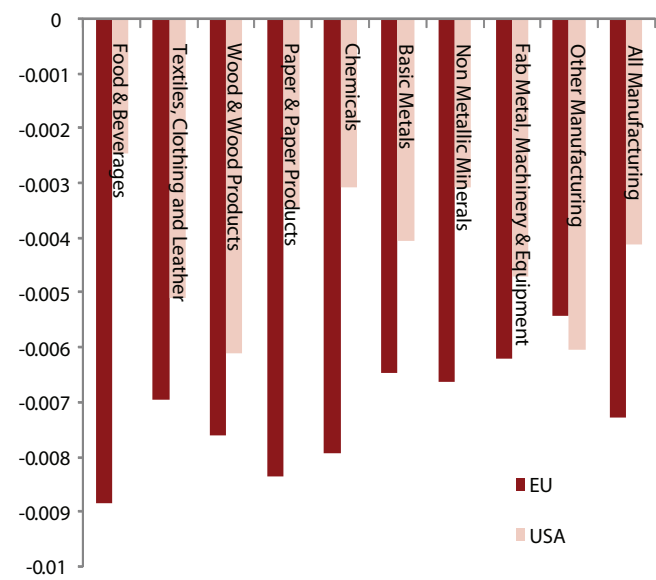

Source: World Bank staff calculations based on data from IMF IFS, Comtrade, Indonesian Manufacturing Census and WDI.

Box 3: How do exports of manufactured goods respond to macro-economic incentives?

Despite a very strong pick-up observed since late 2008 , for most of this decade Indonesia's manufacturing exporters have lost market share and have been largely outperformed by regional competitors (left- and right-hand figures below). While during the mid-1990s Indonesia's exports of manufactures were roughly one fifth of those of China, by 2010, they were only one twentieth. Similarly, another industrial powerhouse like Vietnam also rapidly outpaced Indonesia's. While Indonesia's exports were about six times those of Vietnam in 2000 , the ratio had decreased by a factor of three by 2010.

The relatively sluggish performance of Indonesian manufacturing exports until recently raises the question of to what extent exporters respond to incentives, and how severely they were affected by the adverse macro environment.

Analytical work reveals that exports are highly sensitive to world income, that exporters have been found to respond slowly to price incentives, and that they have been affected by labor costs rising beyond productivity levels, non-tradable price increases and by exchange rate uncertainty. ${ }^{18}$

It takes time for Indonesia's manufacturing exporters to respond to changes in prices. In fact, exports are relatively inelastic to prices in the short run, but unit elastic in the long run. A 1 percent increase in export prices induces an increase in quantities exported of about 0.8 percent initially, which increases to about 1.2 percent after one year. One reason for exports to react slowly is related to the fact that expanding exports usually imply finding new markets, which takes time. In addition, exporters face several constraints that could be delaying supply responses. An example is the difficulty that exporting firms face in obtaining stable flows of electricity supply (as discussed in Policy Note 4 in this series, 35 percent of firms pointed to electricity as a severe obstacle). Another is access to finance. About 8 percent of exporters struggle with finding external sources of finance. ${ }^{19}$

\footnotetext{
We estimated an export supply function for Indonesian manufacturing using data for ISIC 2 digit sectors over the period 1990-2008. The model, following Riveros (1992), expresses manufactured exports as a function of the price of exports, unit labor costs, the price of home goods, exchange rate volatility, and lagged exports. The first thing needed to investigate the determinants of export supply in Indonesia is to understand whether manufacturing sectors are "large" or "small" in international markets. We found that only 4 out of the 16 sectors of Indonesia's manufacturing exports are 'small' enough to be treated as price-takers in international markets. These are the sectors producing paper and paper products, publishing and printing, and transport equipment. The rest seem to have some degree of market power but not with a great deal of influence on world prices. More likely, it is related to the fact that they produce slightly differentiated goods for segmented markets. Results are reported in Tables C \& D of the Appendix.

19 World Bank Enterprise Survey (2009). See Policy Note 4 in this series for a full discussion of the business climate obstacles that manufacturers face in Indonesia.
} 
The increase in unit labor costs of 8 percent per annum over the period has induced an average reduction in export growth rates of 1.6 percentage points per annum. The increases in unit labor costs reveal that the wage bill increased faster than labor productivity. Even if wages in Indonesia are low compared with others in the region, these unit increases affected export performance. When the wage bill increase is above labor productivity growth by 1 percent, exports fall, on average by 0.3 percent. ${ }^{20}$ The sharp and heterogeneous increases in labor costs across sectors seem to have affected export growth across sectors differently. Interestingly, however, exports in sectors that use labor intensively are not responsive to unit labor costs. ${ }^{21}$ It is possible that these sectors, in which labor is a key input, are able to rely on flexible labor contracts to outsource production, insulating them from these costs variations.

Figure 22: Indonesia's manufacturing exports respond to changes in macroeconomic variables (Average export supply elasticities)

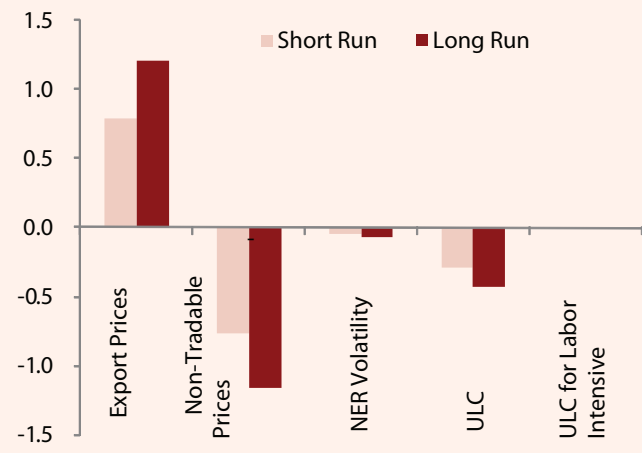

The increase in the price of non-tradables has limited the scope for export growth. A 1 percent increase in nontradable prices reduces exports, on average by 0.77 percent. Non-tradable prices capture non-wage costs faced by firms. Economic growth that outpaced infrastructure facilities and rising incomes from the boom in commodity prices increased demand and prices of non-tradables. In addition, increases in non-tradable prices induce a re-allocation of resources away from manufacturing, affecting export capacity.

As expected, a stable, predictable nominal exchange rate encourages the growth of exports. We find exports to be negatively affected by exchange rate volatility. A 1 percent increase in volatility reduces exports by 0.04 percent on average. Although the effect is economically small, it is very well determined, and robust to different specifications and the inclusion of year effects. ${ }^{22}$

Source: Authors' calculations. Data: Comtrade, Indonesia Census and IMF IFS

Figure 20: Indonesia's share of manufactured world exports has recently recovered after a Figure 21: ...but it is still being outpaced by substantial loss in the early 2000 s...

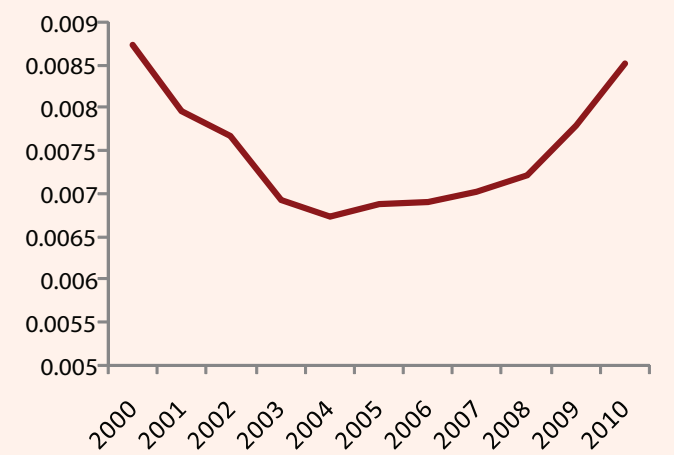

Source: World Bank staff calculations based on Comtrade. dynamic regional competitors

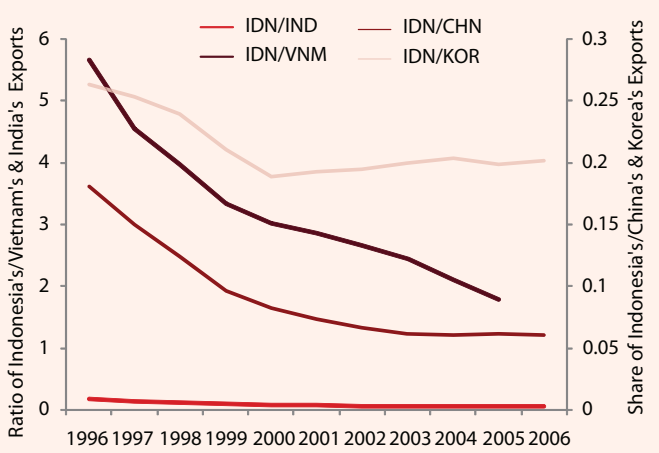

Source: World Bank staff calculations based on Comtrade.

Source: Riveros, L. "Labor Costs and Manufactured Exports in Developing Countries: An Econometric Analysis", World Development, Vol. 20:7, 991-1008, (1992).

Similar estimates are obtained when dollar wages per worker are used instead of unit labor costs. Even if the weight of exporting firms in the total number of firms is not large, it could be argued that there is a specific labor market for exporters, in which only workers with certain characteristics participate. If that's the case, then it is likely that labor costs are endogenous to export growth. For these reason we re-estimated the export supply function instrumenting labor costs using lagged values. The size of the estimated coefficient remained barely unchanged.

21 We cannot reject the hypothesis of a zero effect of unit labor costs on export quantities at conventional significance levels.

22 Given the collinearity between the level and the volatility of the exchange rate, and given the peak of volatility exhibited during the crisis period, we included year dummies to isolate the crisis effects on export growth, which may have been unrelated to exchange rate volatility. The size and significance of the coefficient remained barely unchanged. 


\section{d. Conclusions and Broad Policy Recommendations}

The Indonesian manufacturing sector has experienced a growth recession over the past decade, with growth rates halving after the Asian financial crisis, export growth lagging behind those of competitors, and its employment creation dynamism decreasing. A likely explanation behind these phenomena relates to the adverse changes in the profitability-risk equation that the nonresource-based manufacturing firms faced after the Asian financial crisis, with returns falling and risk soaring, and with especially accentuated effects on labor-intensive sectors. These changes, in turn, were found to be associated with increased competition both in international and domestic markets, putting downward pressure on manufacturing prices, combined with sustained growth for more than a decade and a commodity boom putting upward pressure on non-tradable prices.

Given the changes in the external environment and increased competition in international markets, maintaining macroeconomic stability and removing barriers to improving productivity are important for Indonesia's manufacturing sector to remain competitive. Indonesia is already part of the global economy and exposed to challenges and opportunities from changes in global economic growth. Turbulence in the global economy would impact on Indonesia's manufacturing sector through trade exposure, given the high responsiveness of its exports to world income, or through induced fluctuations in macroeconomic variables. While maintaining macroeconomic stability would help manufacturers in managing risk, policies to support growth would build confidence for manufacturers to maintain a positive outlook on their operations in Indonesia. In this context, making progress in micro-level structural reforms would be essential for compensating manufacturers for the real appreciation of the rupiah and to enable them to effectively face increased international competition. Such reforms would allow Indonesia's manufacturing sector to improve productivity and sustain a higher growth path.

A possible policy framework would involve the following areas

- Strengthening macroeconomic resilience and reducing exchange rate volatility. Putting in place a protocol for crisis management, preparing a contingent fiscal stimulus package, and securing access to currency swaps would reassure the market that, if external conditions worsen, Indonesia has a plan to mitigate the impact on exporters or manufacturers that rely on the resilience of the domestic market. These measures would also help calm the market and reduce speculative outflows of portfolio investment that cause exchange rate volatility, which is costly for manufacturers.

- Reducing logistics costs and facilitating growth of competitive services industries. On average, about 5 to 6 percent of the intermediate input bill of manufacturers is spent on transport and communications. The share is likely to be higher for manufacturing exporters as they regard transportation problems as severe constraints affecting their business. Reducing congestion at ports and having better highways connecting industrial areas would allow manufacturers to manage their logistics more efficiently, hence enhancing their productivity. Also, in Indonesia 24 percent of the intermediate inputs used by the manufacturing sector originate in the service sector. ${ }^{23}$ Because barriers on trade and international competition in services are typically lower than in the goods sectors, one way of boosting productivity in manufacturing would be by allowing more FDI in services ${ }^{24}$

- Reducing regulatory uncertainties. Uncertainty matters for investors because it can delay investment, reduce investment size, or even diminish Indonesia's attractiveness as a designated site for manufacturing investment. Survey and media reports suggest that manufacturers in

\footnotetext{
Source: Input-output tables 2005
}

Arnold et al, 2011. The evidence seems relevant for Indonesia, where restrictions to foreign ownership in some services subsectors are still substantial with the maximum share of foreign equity in the transport subsector being 49 percent, and 57 percent in the telecom sector. 
Indonesia are still faced with uncertainties from the labor law, regional minimum wages, local regulations, and regulations on imports. Some uncertainties in regulation may require informal payments to resolve, while others may be pure rent-seeking activities. Nevertheless, better policy coordination across central government agencies and between central and local governments can help to reduce uncertainties faced by manufacturers.

- Improving the functioning of output/input markets. Indonesia is among the worst performers in terms of entry regulations and closing down businesses. Barriers to entry have been found to harm allocative efficiency and allow firms with poor performance to drag down overall economic productivity. ${ }^{25}$ Rigidities in input markets, such as skilled labor and raw materials, also inhibit manufacturing expansions. Underdeveloped capital markets may be constraining growth of productive small and medium enterprises.

- Building firms' learning capability to innovate. Policies that focus on improving the quality of the skills of the workforce, and that stimulate the adoption of new technologies and innovative activities are the best strategy for long-term productivity growth in the manufacturing sector. The evidence for Indonesia suggests firms that were able to innovate were also better able to respond to the tougher macro and external environment they faced over the past decade.

Hopenhayn, 1992 


\section{Annexes}

Annex Table 1: Profit Margins Estimation

\begin{tabular}{|c|c|c|c|c|c|}
\hline $\begin{array}{l}\text { Dep Var: Profit } \\
\text { Margin }\end{array}$ & (0) & (1) & (2) & (3) & (4) \\
\hline \multicolumn{6}{|l|}{$\begin{array}{l}\text { (Revenue/ Costs } \\
-1 \text { ) }\end{array}$} \\
\hline \multirow[t]{2}{*}{ Export Condition } & $5.163^{* *}$ & $5.902^{* * *}$ & $5.141^{* *}$ & $5.149^{* *}$ & $0.00853^{* *}$ \\
\hline & $(2.061)$ & $(2.047)$ & $(2.061)$ & $(2.062)$ & $(0.00433)$ \\
\hline \multirow[t]{2}{*}{ Time Trend } & $-0.00290^{* * *}$ & -0.000532 & $-0.00299 * * *$ & $-0.00298^{* * *}$ & \\
\hline & $(0.000605)$ & $(0.000441)$ & $(0.000604)$ & $(0.000604)$ & \\
\hline \multirow[t]{2}{*}{$\begin{array}{l}\text { Time Trend * } \\
\text { Exporter }\end{array}$} & $-0.00257^{* *}$ & $-0.00294^{* * *}$ & $-0.00256^{* *}$ & $-0.00257^{* *}$ & \\
\hline & $(0.00103)$ & (0.00102) & $(0.00103)$ & $(0.00103)$ & \\
\hline \multirow[t]{2}{*}{$\begin{array}{l}\text { Nominal Exchange } \\
\text { Rate }\end{array}$} & $0.0571^{* * *}$ & & $0.0570^{* * *}$ & $0.0568^{* * *}$ & \\
\hline & $(0.0126)$ & & $(0.0126)$ & $(0.0126)$ & \\
\hline \multirow[t]{2}{*}{ K/Y Ratio } & $-3.51 e-07^{*}$ & $-3.48 e-07^{*}$ & $-3.51 e-07^{*}$ & $-3.51 e-07^{*}$ & $-3.40 \mathrm{e}-07^{*}$ \\
\hline & $(2.04 \mathrm{e}-07)$ & $(2.02 \mathrm{e}-07)$ & $(2.04 \mathrm{e}-07)$ & $(2.04 \mathrm{e}-07)$ & $(2.00 \mathrm{e}-07)$ \\
\hline \multirow[t]{2}{*}{ L/Y Ratio } & $-0.820 * * *$ & $-0.817^{* * *}$ & $-0.820 * * *$ & $-0.820 * * *$ & $-0.822^{* * *}$ \\
\hline & $(0.0122)$ & $(0.0122)$ & $(0.0122)$ & $(0.0122)$ & $(0.0122)$ \\
\hline \multirow[t]{2}{*}{ Capital Stock } & $0^{* *}$ & $0^{* *}$ & $0^{* *}$ & $0^{* *}$ & $0^{* *}$ \\
\hline & (0) & (0) & (0) & (0) & (0) \\
\hline \multirow[t]{2}{*}{ Growth of GDP PC } & $0.171^{* * *}$ & & $0.172^{* * *}$ & $0.172^{* * *}$ & \\
\hline & $(0.0275)$ & & $(0.0275)$ & $(0.0275)$ & \\
\hline \multirow{2}{*}{$\begin{array}{l}\text { Cost of Capital } \\
\text { (Deposit } \\
\text { Rate*Stock of } \\
\text { Capital) }\end{array}$} & $-5.55 e-11^{* *}$ & $-5.81 e-11^{* *}$ & $-5.56 e-11^{* *}$ & $-5.56 e-11^{* *}$ & $-5.43 e-11^{* *}$ \\
\hline & (0) & (0) & (0) & (0) & (0) \\
\hline \multirow{2}{*}{$\begin{array}{l}\text { Herfindahl Index } \\
\text { Defined at a } \\
\text { Product Level }\end{array}$} & 0.00225 & & 0.00215 & 0.00212 & \\
\hline & (0.00542) & & $(0.00542)$ & $(0.00542)$ & \\
\hline \multirow[t]{2}{*}{$\begin{array}{l}\text { Import } \\
\text { Penetration }\end{array}$} & $0.000430^{*}$ & 0.000262 & & 0.000264 & 0.000267 \\
\hline & $(0.000261)$ & $(0.000242)$ & & $(0.000242)$ & $(0.000242)$ \\
\hline \multirow[t]{2}{*}{$\begin{array}{l}\text { Dummy } 2005 * I m p \\
\text { Pen. }\end{array}$} & $-0.00119^{* *}$ & & & & \\
\hline & $(0.000598)$ & & & & \\
\hline \multirow[t]{2}{*}{ Constant } & $5.664^{* * *}$ & $1.454^{*}$ & $5.853^{* * *}$ & $5.844^{* * *}$ & $0.389^{* * *}$ \\
\hline & (1.168) & $(0.882)$ & (1.164) & (1.165) & $(0.00231)$ \\
\hline Observations & 126,436 & 126,436 & 126,436 & 126,436 & 126,436 \\
\hline R-squared & 31,452 & 0.078 & 0.078 & 0.078 & 0.078 \\
\hline Number of Firms & 0.078 & 31,452 & 31,452 & 31,452 & 31,452 \\
\hline
\end{tabular}


Annex Table 2: Output Price Estimation

\begin{tabular}{lc|}
\hline Dep Var: Growth of Prices & {$[1]$} \\
\hline VARIABLES & $24.35^{* *}$ \\
Export Condition & $(10.95)$ \\
\hline Time Trend & $0.0340^{* * *}$ \\
& $(0.00217)$ \\
\hline Time Trend* Exporter & $-0.0122^{* *}$ \\
& $(0.00547)$ \\
Import Penetration & $-0.00197^{* *}$ \\
& $(0.000843)$ \\
Constant & $-67.67^{* * *}$ \\
\hline Observations & $(4.355)$ \\
R-squared & 143,679 \\
Number of id & 0.002 \\
Robust standard errors in parentheses & 31,602 \\
Source: World Bank staff. &
\end{tabular}

Source: World Bank staff.

Annex Table 3: Export Supply Estimation Results

\begin{tabular}{|c|c|c|c|c|}
\hline & (1) & (2) & (3) & (4) \\
\hline VARIABLES & lqexports & lqexports & lqexports & lqexports \\
\hline \multirow[t]{2}{*}{ Log Export Price } & $0.687^{* * *}$ & $0.600 * * *$ & $0.602^{* * *}$ & $0.796^{* * *}$ \\
\hline & $(0.190)$ & $(0.161)$ & $(0.162)$ & $(0.218)$ \\
\hline \multirow[t]{2}{*}{ Log R.ULC } & $-0.197^{*}$ & & & $-0.285^{* *}$ \\
\hline & $(0.116)$ & & & $(0.136)$ \\
\hline \multirow[t]{2}{*}{ Log Price Non Tradable } & $-0.750 * * *$ & $-0.543^{* * *}$ & $-0.544^{* * *}$ & $-0.766^{* * *}$ \\
\hline & $(0.172)$ & $(0.136)$ & $(0.136)$ & $(0.181)$ \\
\hline \multirow[t]{2}{*}{ Exch. Rate Volatility } & $-12.40^{* *}$ & $-11.04^{* *}$ & $-11.02^{* *}$ & $-11.63^{* *}$ \\
\hline & $(4.978)$ & $(4.781)$ & $(4.788)$ & $(5.232)$ \\
\hline \multirow[t]{2}{*}{ Lagged Log Q. Exports } & $0.344^{* * *}$ & $0.342^{* * *}$ & $0.342^{* * *}$ & $0.340^{* * *}$ \\
\hline & $(0.0504)$ & $(0.0484)$ & $(0.0486)$ & $(0.0529)$ \\
\hline \multirow[t]{2}{*}{ Log Dollar Wages } & & -0.150 & -0.157 & \\
\hline & & $(0.165)$ & $(0.173)$ & \\
\hline \multirow[t]{2}{*}{ Log Dollar Wages*Lab.Intensive } & & & 0.0412 & \\
\hline & & & $(0.348)$ & \\
\hline \multirow[t]{2}{*}{ Log R.ULC*Lab. Intensive } & & & & $0.519^{*}$ \\
\hline & & & & $(0.286)$ \\
\hline Observations & 298 & 298 & 298 & 298 \\
\hline Number of sector & 16 & 16 & 16 & 16 \\
\hline
\end{tabular}

Source: World Bank staff. 
Annex Table 4: Exogeneity Tests

\begin{tabular}{|c|c|c|c|c|}
\hline Sector & Description & $\begin{array}{c}\text { Share on World } \\
\text { Exports (Ave 1989- } \\
\text { 2008) }\end{array}$ & Exogeneity Tests & P-Value \\
\hline 15 & Food and Food Products & $1.56 \%$ & Large & 0.000 \\
\hline 17 & Textiles & $2.10 \%$ & Large & 0.000 \\
\hline 18 & Wearing Apparel & $2.77 \%$ & Large & 0.011 \\
\hline 19 & Leather & $2.85 \%$ & Large & 0.024 \\
\hline 20 & Wood, except furniture & $8.25 \%$ & Large & 0.010 \\
\hline 21 & Paper and Paper products & $1.56 \%$ & Small & 0.105 \\
\hline 22 & Publishing and printing & $0.07 \%$ & Small & 0.384 \\
\hline 24 & Chemical and chemical products & $0.51 \%$ & Large & 0.008 \\
\hline 25 & Rubber and plastics & $0.59 \%$ & Large & 0.001 \\
\hline 26 & Non metallic mineral products & $0.87 \%$ & Large & 0.004 \\
\hline 27 & Basic metals & $0.82 \%$ & Small & 0.100 \\
\hline 29 & Machinery and equipment & $0.11 \%$ & Large & 0.005 \\
\hline 30 & $\begin{array}{l}\text { Office, accounting and computing } \\
\text { machinery }\end{array}$ & $0.38 \%$ & Large & 0.000 \\
\hline 31 & Electrical machinery and apparatus & $0.51 \%$ & Large & 0.000 \\
\hline 32 & $\begin{array}{l}\text { Radio, tv and communication } \\
\text { equipment }\end{array}$ & $0.49 \%$ & Large & 0.002 \\
\hline 33 & $\begin{array}{l}\text { Medical, precision, and optical } \\
\text { instruments }\end{array}$ & $0.16 \%$ & Large & 0.001 \\
\hline 34 & Motor vehicles & $0.07 \%$ & Large & 0.030 \\
\hline 35 & Transport equipment & $0.21 \%$ & Small & 0.782 \\
\hline
\end{tabular}

Note: The null hypothesis to be tested is that the sector is "small" or a "price taker". 


\section{References}

Arnold, Jens, Beata S. Javorcik and Aaditya Mattoo (2011). Does Services Liberalization Benefit Manufacturing Firms: Evidence from the Czech Republic, Journal of International Economics, 85(1): 136-146.

Aswicahyono, H. , D. Narjoko, and H. Hill (2010) "Industrialisation after a Deep Economic Crisis: Indonesia", Journal of Development Studies ,Vol. 46: 6, 1084-1108.

Hopenhayn, Hugo A, 1992. "Entry, Exit, and Firm Dynamics in Long Run Equilibrium," Econometrica, Econometric Society, vol. 60(5), pages 1127-50, September.

IMF (2011), IMF Indonesia Staff report for the 2011 Article IV consultation, Mimeo.

Magud, N. and S. Sosa "When and Why Worry About Real Exchange Rate Appreciation? The Missing Link between Dutch Disease and Growth", IMF Working Paper 10/271 (2010).

Manning, C. and K. Roesad (2007) "The Manpower Law of 2003 and its implementing regulations: Genesis, key articles and potential impact," Bulletin of Indonesian Economic Studies, Taylor and Francis Journals, vol. 43(1), pp. 59-86.

Riveros, L. "Labor Costs and Manufactured Exports in Developing Countries: An Econometric Analysis", World Development, Vol. 20:7, 991-1008, (1992).

Rodrik, D. (2008) "The Real Exchange Rate and Economic Growth", Brooking Papers on Economic Activity.

Rodrik, D. and McMillan (2011), "Globalization, Structural Change and Productivity Growth", NBER 17143.

WTO-IDE-JETRO (2011), "Trade patterns and global value chains in East Asia: From trade in goods to trade in tasks". 


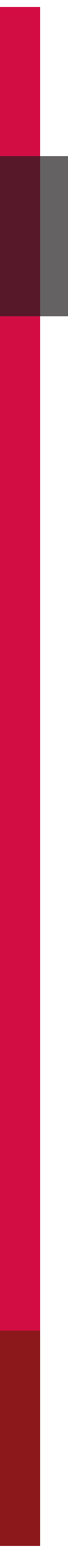

